\title{
Exploring British India: South African prisoners of war as imperial travel writers, | 899-| 902
}

The Journal of Commonwealth Literature

(C) The Author(s) 2017

Reprints and permissions: sagepub.co.uk/journalsPermissions.nav DOI: $10.1177 / 0021989417737594$ journals.sagepub.com/home/jcl

\section{Nienke Boer}

Yale-NUS College, Singapore

\begin{abstract}
During the second South African War (1899-1902), also known as the Anglo-Boer War, the British War Office supervised the transportation of approximately 24,000 South African prisoners of war to Bermuda, St. Helena, and British India. Examining previously unstudied memoirs published immediately following the war by war prisoners held in camps in India and Ceylon, I argue that these texts read not, as one would expect, as prison or war writing, but as travel literature. These authors do not see a conflict between enjoying the benefits of empire abroad while fighting an anti-imperial war at home. The descriptions of landscapes and events in these memoirs suggest a cultural imaginary built on travelling and cultural exchange, as opposed to the insular and nativist Afrikaner nationalism that would follow empire. This article thus contributes to a larger project of examining the precursors of postcolonial nationalism, as well as historical and imaginative links between imperial peripheries.
\end{abstract}

\section{Keywords}

South African War, Anglo-Boer War, empire, travel writing, British India, Ceylon, tourism, prisoners of war, Indian Ocean Studies, Victorian Studies

J. N. Brink, burgher of the Orange Free State, marvelled at the natural beauty of the island of Ceylon: "Instead of marshes and palms, we now see mountains, the sides of which are covered with tea-plantations, forests, and shrubs while here and there mighty precipices are visible. Indeed", he adds, "a railway journey from Colombo to Diyatalawa is really worth the trouble, provided one has a return-ticket" (1904b: 51). Here lies the snag, however: while Brink endorses train travel in Ceylon as enthusiastically as any modern-day tourist in Sri Lanka would do, he is not in possession of a return ticket, nor any ticket at all: he travels as the unwilling guest of the British Empire. One of more than

\section{Corresponding author:}

Nienke Boer, Yale-NUS College, 10 College Ave West, \#0I-I0I, I38609, Singapore.

Email: nienke.boer@yale-nus.edu.sg 
5,000 war prisoners transported by the British Army to Ceylon from the Orange Free State (Oranje Vrijstaat) and the South African Republic (Zuid-Afrikaansche Republiek, also known as the Transvaal), Brink was not on a sightseeing excursion, but travelling to the internment camp where he would spend the next year and a half. And yet, listen to his excitement: "What is that brownish object, lying in the mud? It is a buffalo, which, like a pig, wallows in the dirt, and those two things there? Those are tame buffaloes, drawing a somewhat queer looking implement, which is here called a plough [...] What is up now? Nothing, only a station" (Brink, 1904b: 50). He describes, step by step, all the sights he encounters along the trip, educating the absent reader about the buffalo, its appearance, behaviour and uses. While Brink's memoir, Ceylon en de Bannelingen/Recollection of a Boer Prisoner of War at Ceylon (the text was published simultaneously in English and Dutch in Amsterdam in 1904), also contains passages about his capture in South Africa and experiences in the camp, the undisputed star of the text is the island of Ceylon, "the pearl of the Indian Ocean" (Brink, 1904b: 1). The same trend appears in many other POW memoirs published immediately following the second South African War (18991902): these authors focus more on their travel adventures than on deprivation and suffering. I argue that the writings of these war prisoners, nascent British subjects transported at the height of the age of empire, suggest an imperial imaginary built on travelling and cultural exchange, as opposed to the insular and nativist nationalisms that would follow empire. These writers see no contradiction in enjoying the fruits of empire - servants, trains, tea plantations - abroad, while fighting an anti-imperial war at home.

Literature, both scholarly and fictional, about the second South African War is dominated by descriptions of the concentration camps internal to South Africa, where women, children, and African combatants were interned. The concentration camps were poorly managed, and the mortality rate for women and children was extremely high (Jewell, 2003; Smith and Stucki, 2011). Compared to the victims of the concentration camps, the transported war prisoners play a marginal role in the way the war has been studied and commemorated, as Isabel Hofmeyr (2012) also argues in a recent article calling for the re-evaluation of war prisoners in the framework of the developing field of transnational Indian Ocean historiography. Hofmeyr argues that recontextualizing the war deportees to South Asia within the history of free and unfree migration across the Indian Ocean allows us to expand emerging scholarly understandings of "the rich transnational experimental imaginings engendered by the epic imperial mobility of the nineteenth century" (2012: 363). While Hofmeyr's article begins to suggest how the POWs fit into larger patterns within the Indian Ocean world, no one has engaged intensively with the literary materials — such as journals, letters, memoirs, and newssheets - written by the war prisoners in British India in this context. By entering these neglected texts into dialogue with the larger imperial imaginary of the nineteenth century, I argue that the internees portrayed themselves as tourists, not just as victims of British transportation. ${ }^{1}$ Their writings evidence their ability to reconcile a cosmopolitan identity enabled by empire with their loyalty to the beleaguered republics they left behind.

Critical writings on imperial and colonial travel narratives have largely focused on the unequal power relations imbedded in travel writing: the imperial traveller as possessed of the means and authority to both travel, and narrate his (most often his) experiences. ${ }^{2}$ Paul Smethurst, in the introduction to Travel Writing, Form, and Empire, describes the most significant of the "ideologically informed asymmetrical relationships" upon which travel writing is constructed as the divisions into "traveller/travellee, observer/observed, and 
narrator/narrated" (2008:1). The typical travel writer in these texts embodies the covetous colonial gaze, seeing, and writing, with "imperial eyes", as Mary Louise Pratt (1992) famously claims. Other theorists have called for a more nuanced reading of the power relations embedded in imperial and colonial travel writing, moving beyond the idea of a monolithic Eurocentrism, or for an expansion of the kinds of texts read as travel writing. For example, Stephen Keck (2015) argues that soldiers' memoirs from colonial Burma can be considered as travel writing, "partly because soldiers often participate in some of the same activities (such as 'sightseeing') as tourists" (390). Furthermore, Jessica Howell, analysing the letters written by British colonial nurses in Africa and the Caribbean, argues that these letters "blurred the boundaries between travel and adventure narrative, reportage and letter writing" (2013:74). The South African war prisoners are in a comparable position to these soldiers and nurses, in that they also traverse new countries - as such, their observations will necessarily be written from a tourist perspective. However, unlike the soldiers and nurses, who still embody the power of the British Empire, the war prisoners are the conquered, not the conquerors. When they sightsee, they do so at the whim of the British Army, or having escaped its internment camps. The first edition of the Castle Line shipping company Guide to South Africa states that it is for the use of "Tourists, Sportsmen, Invalids and Settlers", whereas the 1848 Guide du voyageur en Algérie lists "le savant, l'artiste, l'homme du monde et le colon" as its target audience - war prisoners are, then, certainly not the expected nineteenth-century tourists (Behdad, 1994; Mackenzie, 2005).

These are thus not the typical "seeing-men" (1992: 7) Pratt describes, surveying foreign territories with an expansionist gaze. Furthermore, the war prisoners fall under the category of "belated travelers", in Ali Behdad's (1994) terminology: travelling in the age of the guidebook, when "tourism and European colonialism had already turned the exotic into the familiar" (1994: 92). Why, then, do these memoirists deploy the tropes of earlier imperial travel writing, as identified by Pratt, J. M. Coetzee (1988), Behdad, and others, in their descriptions of people and landscapes? I argue that they do more than just echo imperial clichés (Ceylon as the "pearl of the Indian Ocean"), as we have seen Brink doing. Their travel writing is organized around a specific narrator, telling the story of a specific journey (as opposed to the guidebook, in which the "statements and their speakers are dissociated from one another" (Behdad, 1994: 40)), the natural landscape is described largely in terms of the sublime (mountains, mighty precipices), and the native inhabitants are naturalized as part of the landscape (for example, the planters of tea and tamers of water buffalo are absent from Brink's description above). The answer to the question of why these authors turn to the narrative formulas of imperial travel writing lies in an examination of both the historical circumstances connecting South Asia and South Africa, and the community that existed within the POW camps themselves.

The British Army turned to "the Empire as gulag" (Hofmeyr, 2012: 365) as a strategy for dealing with Boer war prisoners during the second South African War (the lesser-known first South African War, 1880-1881, had seen the British Army defeated by the South African Republic). During the course of the second South African War, the British military authorities transported more than 24,000 war prisoners to different parts of the empire. Using islands within the Empire (Bermuda, Ceylon, and St. Helena), and the mainland of India, to house POW camps can be seen as a natural extension of penal deportation (Anderson, 2009). 5,127 POWs were transported to Ceylon between August 1900 and May 1901. From April 1901, 9,131 POWs were transported to India, where they were kept in a 
number of different camps in the Punjab, Bengal, Madras, and Bombay Commands (War Office, 1905: 4-5). A separate group of 1,443 Boer war prisoners, captured by the Portuguese in Mozambique, were transported to Portugal and held in six Portuguese camps (Ferreira, 1997). Prisoners were allowed to return to South Africa at the conclusion of the war on 31 May 1902, if they agreed to take an oath or sign a declaration of allegiance to the British crown. A few refused to sign. These "bittereinders" (bitter-enders) were eventually resettled elsewhere, in British India, Malaya, or the Dutch East Indies.

In his memoir, Brink writes: "It now strikes us as a remarkable fact, that up till now, we knew nothing whatever of this beautiful island [Ceylon], with its marvellous scenery. No doubt our attention was too much riveted on another island in the North Sea, which was alone considered worth our notice" (1904b: 51). He criticizes the occlusion of other parts of Empire by the prominence of Great Britain. Figure 1, entitled "Our Journey to Ceylon", is a map of the journey from South Africa to Ceylon - these maps, printed in Colombo, must have been popular souvenirs in the camps, as I found numerous examples in the archives.

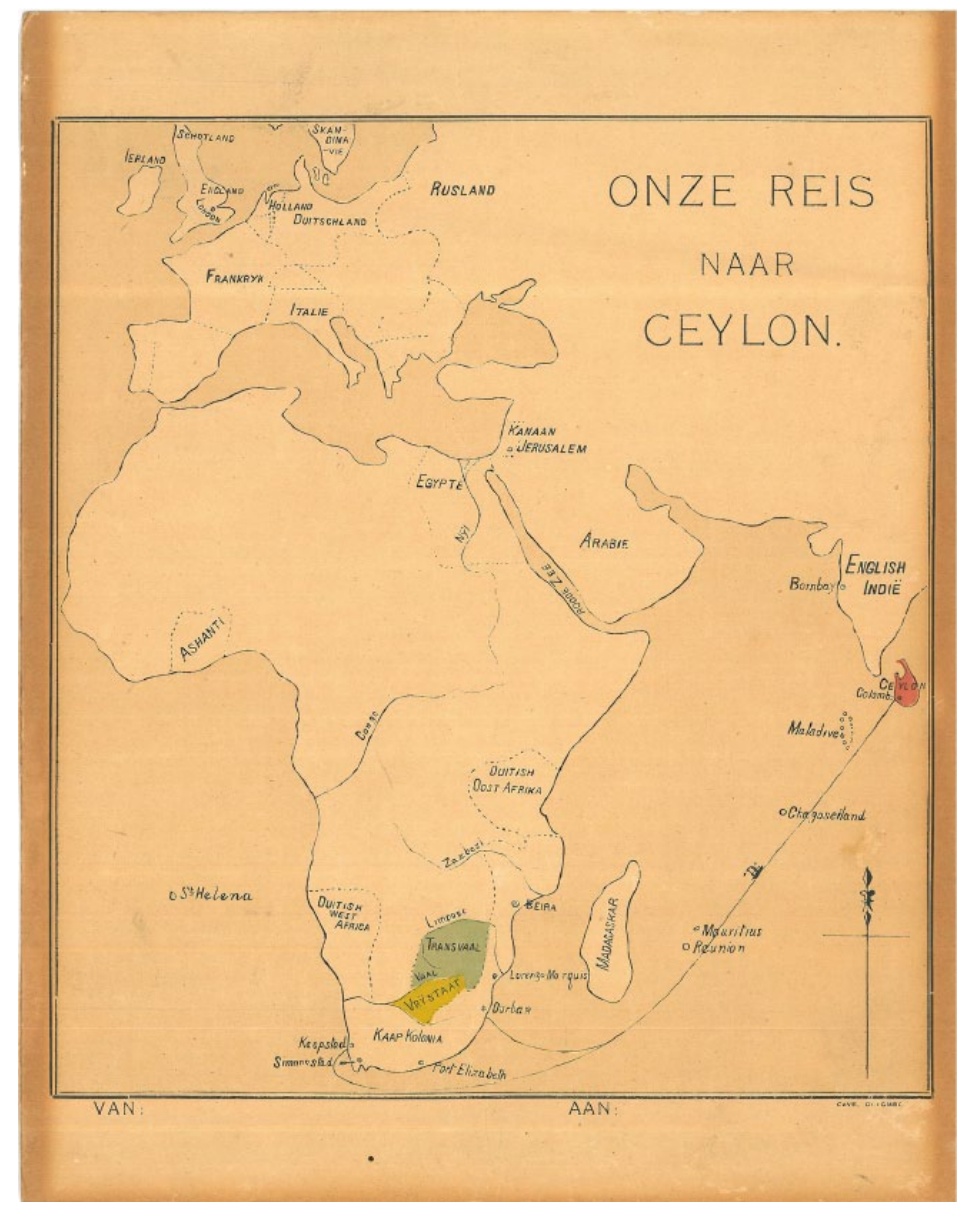

Figure I. Onze Reis naar Ceylon [Our Journey to Ceylon). Acquisition no. 02016/00002. War Museum of the Boer Republics, Bloemfontein, ZA. 
The map visualizes an alternate imperial imaginary, in which connections between different parts of the British Empire are not figured as passing through London, but directly link the peripheries. By the end of the war, more than 10,000 South Asians had served in the second South African War as "auxiliaries" (non-combatant troops) (Reddy, 1999). Famously, Mohandas K. Gandhi organized the Voluntary Ambulance Corps, consisting of 543 Indian South Africans supporting the British war effort in South Africa (Desai and Vahed, 2016). Indian newspapers also featured extensive coverage of the war (Datta, 2011). The second South African War thus highlights various ways in which SouthSouth connections were figured at the height of British imperialism.

The autobiographical accounts by former South African war prisoners published in the early years of the twentieth century are, generically, a combination of personal memoir and what would at the time have been called a travel book or an itinerary, a term initially used for an account of a journey. ${ }^{3}$ Events are thus arranged chronologically, largely following the structure: capture (and/or arrival in British India) $\longrightarrow$ captivity $\longrightarrow$ release (or escape) and return. Memoirs were mostly published in Europe, in English, Dutch, and German. Three POW narratives were published in the Netherlands (a pamphlet in 1901, two books in 1904), one in Berlin (1903), and one in Pretoria (1905), while the place of publication of one text, dated 1902, is not listed. ${ }^{4}$ Many more narratives are translated into Afrikaans and published in the 1930s and 1940s, when, as I discuss below, Afrikaner nationalists recuperate these previously neglected figures. The texts by war internees in South Asian camps describe the events which befell the narrators during their captivity while also educating the reader about the context for these events - including descriptions of the landscape, history, and culture of British India. If these memoirs are neither able to claim the novelty and adventure of the explorers' narrative, nor contain the level of detail necessary to serve as guidebooks for future travellers, how do their authors view the intended audience of their texts, and whence does their authority derive?

The Preface to Brink's Recollections of a Boer POW in Ceylon reads: "I have tried to give in this little book a short sketch of the history of the island of Ceylon - the pearl of the Indian Ocean - , and to that I have added a description of some of the natural scenery of the island, in order to give the reader a faint idea of a place, which may be considered as an unknown country to the Africander [sic]" (1904b: n.p.). Brink's authority as narrator and the novelty of his text stems, then, from his position as war prisoner: the titles of both English and Dutch texts stress that his ability to write about Ceylon is inextricably linked to his experiences as a POW (in English) or "exile" (in Dutch). At a time when tourism had routinized the exotic (the first India edition of the publisher John Murray's well-known Handbooks for Travellers was published in 1859, for example, and in 1892, it expanded to include Ceylon (Handbook, 1892)), Brink's unusual experience as a war prisoner provides the text with a sense of adventure. Brink's description of the book as "little" (using the diminutive boekske in Dutch) is thus strategic: he is not trying to create, or compete with, an encyclopedic guidebook. At the same time, Brink claims that, at least for the "Africander", this is still an unknown and exotic space. He can take on the mantle (and the tropes) of both explorer and educator. While the novelty of the text might derive from his experience as war prisoner, Brink's primary stated purpose is not to tell his readers about this experience, but rather about the island itself. More than half of his text describes the island and its historical context, while his life as a POW comes across as peripheral to his experiences as a tourist. Even if the frontispiece of his text is a 
photograph of a graveyard, most of the photographs Brink includes — "a jungle view in Ceylon", "a Banyan tree", "the artificial harbour of Colombo", "catamaran with divers", "a Cingalese [sic] lady", to name but a few - suggest a narrative of travel and exploration, not suffering and confinement.

Part of the reason for Brink's enthusiasm for Ceylon, and his eagerness to describe it in detail for his audience, is a persistent sense of familiarity. In the chapter entitled "First Impressions of a Prisoner", Brink writes:

Ceylon! As a youngster I would sing:

"Even if a cool wind blows

From Ceylon's fragrant land"

Ceylon! As a lad I had learnt: Ceylon-Colombo on the coast. But that was it! (1904a: 47)5

Brink would have learnt about Ceylon as a child because the island had once been a governorate of the Vereenigde Oost-Indische Compagnie (VOC), the United/Dutch East India Company, the same company that originally established a trading post at the Cape of Good Hope to restock the ships making the trip between Europe and Asia. Ceylon thus became a familiar name within Dutch-speaking territories, with certain tropes for describing the island readily available to these travellers. This moment in the text recalls circulation within an earlier trade empire. The first forced migrants travelling between these two geographic regions had been slaves brought to the Cape from parts of South Asia (Dutch India) and South-East Asia (Dutch East Indies) under the auspices of the VOC. When Brink arrived at Ceylon in 1901, he was thus revisiting an earlier history of imperial displacement. Ceylon was a familiar and evocative term to a boy growing up in South Africa. This also explains why Brink describes the Dutch Reformed Church in Colombo at great length: "On the walls are still to be seen the coats-of-arms of the old Dutch Governors, and in the pavement there are many tombstones with Dutch inscriptions" (1904b: 31). The imperial gaze of the Boer war prisoners is a complex outcome of Empire: South Africa, Ceylon, and India are doubly bound, by Dutch and British imperial projects. Brink and his fellow POWs in Ceylon do not have expansionist intentions here, or any proprietary stake in the landscape they describe, and yet they are only there because of this imperial history. Pratt explains how eighteenthand nineteenth-century "[ $\mathrm{t}]$ ravel books [...] gave European reading publics a sense of ownership, entitlement and familiarity with respect to the distant parts of the world that were being explored, invaded, invested in, and colonized" (1992: 3). Here we see how this sense of familiarity also manifests between fellow colonies, such that a part of the world initially described as unknown to the Afrikaner is shown to be uncannily familiar, to the extent of returning Brink to his childhood.

The shared imperial history of Ceylon and South Africa helps to explain why Brink turns to the tropes of travel writing to narrate his experience, but this choice is unexpected, and not just because one expects a different narrative from a war prisoner. The Boer soldiers are generally seen as barely literate, or at least, as one Afrikaans book review from 1934 has it, "the pen was in most cases more terrifying than the gun for the combatants" (Die Burger, my translation). In a British travel book penned by Winston Churchill's father, Lord Randolph Churchill, in 1891, he writes of the Boer farmer: "“He 
is perfectly uneducated. With the exception of the Bible, every word of which in its most literal interpretation he believes with fanatical credulity, he never opens a book, he never even reads a newspaper. His simple ignorance is unfathomable"' (qtd. in Van Wyk Smith, 2003: 429). The Boer reputation for ignorance of the lettered world is thus doubly determined: on the one hand, the British are invested, at the turn of the twentieth century, in underlining what M. Van Wyk Smith (2003) describes as "Boer racial ambiguity": "a question of whether the Boers were 'another white race or not"' (430). Pro-war British writers are thus invested in erasing the traces of Europe, and European culture, from depictions of the originally Dutch and French settlers who would become the Afrikaners. Even positive accounts of the Boers in British travel writing from this period compare them to "Horace's description of the Roman peasant soldiers who defeated Pyrrhus and Hannibal" (James Anthony Froude, qtd. in Van Wyk Smith, 2003: 430) — while not the barbarians of Churchill's dispatches, the Boer as Roman peasant is still not cultured or highly civilized. The tendency in British travel literature on South Africa is thus to treat the Boers as objects of the imperial gaze, and, as such, their embrace of the genre of travel writing is surprising.

On the other hand, this ideal of peasant simplicity will be picked up by Afrikaner nationalists in the 1930s, who have very different reasons for stressing the Boer fear of the pen. Now, the simplicity of the author guarantees his honesty: "In the simplicity of the tale lies its attraction: this is an unvarnished [onopgesmukte] retelling of extraordinary bravery and innovation, seen from a truly Afrikaans point of view" (Die Burger), the 1934 reviewer continues. The "truly Afrikaans point of view" lacks literary flourishes — this is an honest, uncorrupted soldier telling his simple tale. These two perspectives on the Boer soldiers, though created for very different political purposes, have been mutually reinforcing. Even today, people are surprised to hear about the range of writings that emerged from the POW camps. The camps hosted boxing matches, but also debates; prisoners carved and sold wooden walking sticks, but also operated photographic studios or offered classes in French (for more information on activities in these camps, see Brohier (2015)). The three camp newssheets from Diyatalawa, De Prikkeldraad (Barbed Wire), the Diyatalawa Dum-Dum, almost immediately renamed the Camp Lyre, and De Krijgsgevangene (The War Prisoner), containing articles in four different languages, reveal an active camp intellectual life. For example, De Prikkeldraad dedicates closely-written pages to detailing war news (a section entitled "De Brandwacht", or "The Sentry"), news from the rest of the world ("L'echo du monde vivant", or "Echoes from the Living World"), news from the camp itself ("Among the Bungalows"), episodes from the war ("Van de Kopjes", or "From the Hills"), and advertisements (De Prikkeldraad, 1900). These publications were written by hand, and reproduced through an early version of the mimeograph, the cyclostyle. Admittedly, many of the Boer war prisoners were undoubtedly artless sons of the soil, and some of the articles in the newssheets were clearly written by Uitlanders - foreigners sympathetic to the Boer cause. The stereotype of the unlettered, uncivilized Boer soldier, however, fails to reflect the true situation in the camps.

The intellectual life in the camps also helps to explain why the tropes of travel writing were adopted by the Boer memoirists. The camp newssheets suggest that a sophisticated awareness of broader British imperial discourse did exist in the camps. A section from a short poem entitled "Diyatalawa", which appeared in De Prikkeldraad in 1900, reads: 
This is a chance for a cheap sea-trip

Finest place for taking a holiday.

They speak of Paris, Rome and Naples

And places known of yore.

But there are none which ever rivalled

With this cheap healthy resort [...] (De Prikkeldraad, 1900).

The prisoners here satirically depict themselves as tourists, taking a "cheap sea-trip" abroad - aligning themselves with travellers on the package tours arranged by Thomas Cook and Son starting in 1841, or the Union-Castle Line cruises, formed in 1900 by the amalgamation of the Union and Castle Shipping Line companies, which also transported British soldiers to South Africa during the war. While John M. Mackenzie (2005) points out that the British Empire was also an empire of travel, I would stress that the technology of war and empire-building lent itself well to tourism, and vice versa. The word "trip" also appears, pertinently in English, in the popular Afrikaans folk-song "Sarie Marais", which originated during the second South African War. The speaker here says of the British Army: "They throw you on a ship for a long, long 'trip'| The devil only knows where to" (FAK Elektroniese Sangbundel, 2014, my translation). "Trip" was also the term used by the Victorian British explorer and travel writer, Sir Richard F. Burton, in reference to his travels in Africa: Two Trips to Gorilla Land and the Cataracts of the Congo (2011 [1876]). The camp newssheets suggest that war internees commonly thought, and even joked about, the journey to British India in relation to tourism and exploration. This helps to explain the memoirists' deployment of travel writing tropes in their narratives. These memoirs and the camp newssheets thus partake of a larger imperial culture of travel, tourism, and mobility.

However, even though Brink and others can envision themselves as imperial tourists, their narratives are complicated by patriotic references to the Boer Republics left behind. Brink's text begins with the history of European conquest: "Ceylon visited by the Nations of Europe", where he writes that Ceylon deserves the title, the "pearl of the Indian Ocean", as "not only does its shape resemble that of a pearl, but its riches, its precious stones, and above all, its beautiful scenery, entitle it to that name" (1904b: 1). His history of Ceylon starts with occupation by the "Cingalese [sic]" and the "Malabars" [Tamils]. He then proceeds: "These two Indian tribes were, indeed, like two dogs fighting for a bone; other nations successively ran away with the coveted prize. These nations were, in the proper order of succession, the Portuguese, the Dutch, and the English" (1904b: 1). Brink tells the story of the conquest of Ceylon by implicitly creating parallels between the Sinhalese and the Boers as early, effective occupiers, with the British and Portuguese as outsiders, and fairly incompetent ones at that. The Sinhalese, in resisting the Portuguese, are depicted as "inferior in armament to the invaders, their mode of fighting consisted in employing stratagems rather than actual force". They are "an observant and ingenious race"; "[u]nited, full of patriotism, and well-protected behind their mountainramparts, who proved a very dangerous enemy to the Portuguese" (1904b: 4). The parallels to the Boer republics in South Africa, resisting the British through guerilla warfare, 
are hard to miss. This positive view of the Sinhalese, however, does not extend into the author's present - Brink sees them as a degenerate people whose prime lies far in the past. "It is a sad idea, that a nation, once so mighty and powerful, should have sunk so deeply, after having once lost its energy, and should now fall into a state of absolute apathy", he opines later (40). This denial of coevalness ${ }^{6}$ is typical of Orientalist travel writing and guidebooks, used to "distance the Other, not to bring him or her closer to the European tourist”, as Behdad (1994) argues of guidebooks. However, in Brink's case, it has a more urgent implication: to Brink, this is a warning to Afrikaners about their possible fate, following defeat by the British. Brink's retelling of the history of Ceylon is thus not simply neutral background information, as would be provided in most itineraries and guidebooks. He is interested, not in the history and customs of the people of Ceylon for their own sake, but in deducing what the history of Ceylon predicts for the future of South Africa. Brink's residual loyalty to the Boer republics thus infiltrates the travel narrative, in a similar way to how his travelling without a return ticket affects his initial appreciation of the Ceylonese countryside.

The spectre of the Boer republics and their fate thus continues to trouble the travel narratives produced by the war internees. Within the Boer POW memoir canon, tales of escape abound, and were clearly popular amongst readers. Tales of escape provided a powerful counter-narrative to the reality of defeat in South Africa. The authors pit themselves as clever underdogs against the might of the British Empire. In the Preface of J. L. De Villiers's (1904) Hoe Ik Ontsnapte: Verhaal van een Merkwaardige Ontsnapping van een Boer uit Engelsch-Indie (How I Escaped: Tale of a Remarkable Escape of a Boer from British India), the author writes: "'Tis no war book, but a simple true tale of what I experienced. Were the reading of this to give the reader as much pleasure as the escape caused me anxiety and suspense, I would be satisfied indeed" (1904: n.p., my translations throughout). The stakes of the text are set out here: this is a "simple true tale" intended to give the reader "pleasure". The author claims to see himself as an entertainer, not an educator, hence the disclaimer that this is not a "war book". A war book would presumably have to address the Boer republics' final defeat, whereas this book can simply tell the tale of one small, "remarkable" victory. By depicting himself as a daring traveller in a foreign land, rather than a victim of British imperial power, De Villiers rewrites his own narrative but also the narrative of the Boer republics, allowing them a certain dignity in their loss. The two authorial identities - loyal burgher of the Boer republics and imperial travel-writer — can thus be reconciled through the narrative of escape.

De Villiers's escape attempt was based on the somewhat far-fetched idea of disguising himself as an Indian by blacking his face and exposed skin with burnt cork. In this, we can perhaps see shades of Richard F. Burton, who famously infiltrated a pilgrimage to Mecca disguised as an Afghan born in India. De Villiers would leave the camp with the group of Indian employees who manned the small store in the camp: a plan that reads more like a music-hall joke than a serious endeavour. Boer officers were treated graciously in the camps, and were usually assigned servants: as Hofmeyr explains, "“white men' could not be seen doing menial labour in a colony" (2012: 366). In order to gain the necessary local knowledge, De Villiers has to quiz his servant on which class of Indians generally travel on trains. He also needs to learn how to pronounce the name of the 
station he wants to go to, Villupuram, like a local: "The stations in India have, as we see it at least, barbaric names, not even to mention the way in which they are pronounced, or rather expelled, by the local population" (1904: 34-35). Even though De Villiers's attitude remains dismissive towards the local population throughout, his escape attempt does force him to become better acquainted with his servant. For example, he quickly learns that folding his turban correctly is much more difficult than he imagined, and he has to get his servant to fold the turban for him. He observes that most Indians either go barefoot or wear light shoes without socks, so he has to leave his socks behind, causing him severe discomfort. De Villiers thus receives a visceral education in the physical experiences of the local inhabitants. As he says, while the POWs would visit nearby towns while on parole, "in general we were completely in the dark about all habits and customs of the Indian population" (1904: 32). In order to carry out his escape, De Villiers needs this local knowledge of "habits and customs". He also has to establish exactly where the French-British border is: "The rest of the information about the exact location of Pondicherry, the distance from Villupuram to the border, and the description of Pondicherry, I mostly got out of a book, a kind of travel guide to India, which also contained a map. We had obtained this book on board our ship" (1904: 36-37). De Villiers here literally becomes a tourist with a guidebook in hand!

The interactions between De Villiers and his manservant, and the Boer war prisoners and the local population more broadly, shed light on the racial dimension of this "contact zone", as Pratt (1992) names the "social spaces where disparate cultures meet, clash, and grapple with each other, often in highly asymmetric relations of domination and subordination" (1992: 4). In Ceylon, the local newspaper, the Ceylon Observer, documents a fascinating encounter in Diyatalawa: the Nawab of Bhalwalpur's visit to the camp:

Seeing the immense impression so many thousands stalwart prisoners in our midst (carried some thousands of miles from their own land across the ocean) has made on our own Kandyans and their Chiefs, we can conceive that it would be an admirable object-lesson for any dubious or recalcitrant Indian ruler or Chief if such were induced to visit Diyatalawa. Not that the Indian Nawab, we have referred to, is of that class. On the contrary he is as loyal as he is intelligent and well-educated, and will, we expect, make an admirable ruler in his important State (Ceylon Observer, 1900: 1206).

Here the Boer prisoners, and the fact that they have been transported "some thousands of miles", become an "object-lesson" to local rulers, serving both to impress and to enforce obedience. The contact zone in which the war prisoners, the British colonial government, the local Ceylonese, and the Nawab (ruler) of Bhalwalpur (a princely state in Northern India) encounter each other is defined by racial and class complexity. The Nawab is "loyal, intelligent, and well-educated": depicted here as superior to both "our own Kandyans" and, arguably, the Boer prisoners, whom he can observe. It is interesting to note the role played by the war prisoners in the British strategy of divide and rule. The war prisoners themselves, on the other hand, evince great interest in local history and religion. A former Boer war internee, J. L. P. Erasmus, following the war published a series of articles on Hindu epics and Indian history in Indian Opinion, a newspaper founded by M. 
K. Gandhi in South Africa (Hofmeyr, 2013). Brink also includes a short description of a version of the South Asian epic, the Ramayana, in his memoir. However, the attitude evinced by the South African prisoners towards the South Asians they encountered remained undeniably racist: while De Villiers acknowledges the importance of learning local "habits and customs", he does so by in the same breath complaining about the "barbaric names" that are "expelled" [uitgestooten] rather than pronounced. As Brink's narrative suggests, the authors distinguish between what they perceive as the rich cultural heritage and the contemporary, degraded state of the native people they encounter. These authors thus view themselves as superior to the local population, who can, however, be co-opted into resisting the shared imperial yoke of the British. The dense contact zone instantiated between "also-colonized other[s]" (Soske, 2017: 3) in the war internment camps complicates our understanding of racial and regional hierarchies amongst fellow imperial subjects.

Analysing the early published POW memoirs, the authors' descriptions of their experiences in India suggest that, at that historic juncture, they could reconcile patriotism for the Boer republics with a more cosmopolitan, nomadic identity as offered by empire. These two identities, affiliated with the nation and with empire, were not opposed in the minds of the war prisoners. Manu Goswami, writing a sociohistoric genealogy of nationalism, reminds us that " $[\mathrm{t}]$ he era of the late nineteenth- and early twentieth-centuries was defined by a structured dynamic between high nationalism and high imperialism; it was an age simultaneously of empire and nation" (2002: 787). Even though later forms of nationalism would cast these two forms as mutually exclusive, this "structured dynamic" was experienced in more unsettled ways at the time.

By briefly contrasting the earlier journals with an exemplary account published in 1936, I shall demonstrate how the figure of the war-prisoner-as-tourist was erased from these later narratives, while the nascent nationalist impulse was foregrounded. The 1930s and 1940s mark the consolidation of power by the National Party in South Africa (cemented in their decisive 1948 electoral victory) on a platform stressing the suffering and forbearance of the Afrikaner people, both during the Great Trek and the South African Wars. A. P. Burger's Worsteljare: Herinneringe van Ds. A. P. Burger, Veldprediker by die Republikeinse Magte tydens die Tweede Vryheidsoorlog (Years of Struggle: Memories of Rev. A. P. Burger, Chaplain of the Republican Forces during the Second Freedom War), based on a journal kept by Burger during the war, was published in 1936. The journal was edited by his son, A. J. V. Burger, who describes his editing process as part translation, part reworking. A. P. Burger was a Dutch Reformed minister who had been a chaplain attached to the Boer forces during the war, before being captured in February 1902. He was sent to POW camps in Shahjahanpur and, eventually, Bhimtal, both in India. His memoir is self-consciously framed as providing a retrospective view on the war, showing how it fits into the grand narrative of the Afrikaner nation: "He who controls the fate of nations apparently used the war as a means in His hand to unite the Afrikaner people and to build a greater nation [volk] for South Africa" (Burger, 1936: 1, my translation). The text regularly incorporates similar editorializing comments (probably added by his son), such that one has a sense of two temporal viewpoints being combined: one, a day-by-day perspective of life in the camp, and the second, a retrospective, God's-eye view in which the immediate 
suffering of the Afrikaner people makes sense as part of a longer historic narrative arc. In Burger's text, the landscape is described as beautiful, but then quickly dismissed:

A lovelier environment for a prisoner of war is hard to imagine. But this beauty was not a gift from the enemy to us; it was the silver lining that the Almighty allowed to shine through our dark clouds. This natural beauty only made us long more for sunny South Africa, our beloved fatherland $[\ldots]$ No, rather place me in the charcoal-grey old Karoo or on the dry flatlands of my old Transvaal and let me there long for more beautiful parts of the world, but just don't let me wither away again in the paradise of nature as an exile in a Khaki-camp (Burger, 1936: 149-150).

Compared to the earlier published accounts, where the landscape is described as if the reader will one day visit it, or at least wants to take a vicarious trip there, here we see a retrospective corrective glance: the foreign landscape only serves to remind the exile of his fatherland. The more beautiful the scenery is, the stronger his longing to return to the "charcoal-grey old Karoo or dry flatlands of my old Transvaal". J. M. Coetzee, in White Writing, stresses the task given to Afrikaans poetry in the early decades of the twentieth century to "find evidence of a 'natural' bond between volk and land, that is to say, to naturalize the volk's possession of the land" (1988: 61). Burger appeals to this "natural" bond, increasingly well established by the 1930s, in his rejection of the "paradise of nature" for the "charcoal-grey old Karoo". The imperial tourist has been fully recast as the nationalist patriot in exile.

"Tourists, Sportsmen, Invalids and Settlers": so do the guidebooks of the late nineteenth century imagine the travellers who would use them. However, alongside this empire of free travellers there exists another empire, a shadow empire of coerced or forced migration which persisted after the abolition of the slave trade and slavery. These travellers range from the servants, soldiers, and nurses who serve, protect, and heal the tourists, sportsmen, invalids, and settlers listed above, to indentured labourers, war prisoners, and penal deportees. As Clare Anderson argues, "colonial innovations in incarceration and confinement", specifically around penal deportation, informed the practices and experience of indenture (2009: 93). The ships used to transport South African war prisoners to British India also carried returning Indian troops, who served as auxiliaries in the war. The lines of historical continuity between systems of unfree migration are obvious. These two empires - the empire of tourism and colonial settlement and the shadow empire of war, labour, and imprisonment depend on the same technology and infrastructure: steamships, railways, telegraphs, and so on. Perhaps we should then not be surprised to see overlaps, however counterintuitive these might seem, in the cultural imaginary of empire amongst these groups of free and unfree migrants: soldiers sightsee (Keck, 2015), nurses promote the health benefits of tropical climates for travellers (Howell, 2013), and indentured labourers settle (Boer, 2016). This analysis of the memoirs of South African war prisoners contributes towards the project of examining how the subjects of this shadow empire experienced imperial mobility, and how they imagined their identities as mediated both by local loyalties and larger imperial narratives. This project challenges simple dichotomies of resistance and collaboration, free and unfree migration, and imperialism and nationalism through careful analysis of the narratives produced by individual subjects of the British Empire. 


\section{Acknowledgments}

I would like to thank the War Museum of the Boer Republics in Bloemfontein for their permission to reproduce figure 1, "Onze Reis naar Ceylon."

\section{Funding}

This research received no specific grant from any funding agency in the public, commercial, or not-for-profit sectors.

\section{Notes}

1. Bill Nasson also refers to the deportation of Boer war prisoners as "enforced war tourism on the peripheries of empire" (2010: 235).

2. For more on female travel writers, see Sara Mills (1991).

3. While we would refer to these texts as travelogues today, the term does not appear in English until 1903, when it initially referred to a lecture delivered about a journey taken by the speaker (usually illustrated by slides) (OED, 2017).

4. Namely: Van der Hoeven (1901); Brink (1904); De Villiers (1904); Von Braun (1903); and Van der Watt (1905).

5. The English version leaves out the lyrics of the song, so I have translated this section from the Dutch version: "Ceylon! Als jongeling heb ik weleens gezongen: 'Al waait een koele luchtje/ van Ceylons geurig land'. Ceylon! Als knaap had ik eens geleerd: Ceylon — Colombo op de kust. Maar dat was dan ook al!"

6. This is a reference to Johannes Fabian's well-known discussion of the denial of coevalness in ethnographic discourse in Time and the Other: How Anthropology Makes its Object (2002/1983). Fabian defines this as "a persistent and systematic tendency to place the referent(s) of anthropology in a Time other than the present of the producer of anthropological discourse" (31).

\section{References}

Anderson C (2009) Convicts and coolies: Rethinking indentured labour in the nineteenth century. Slavery and Abolition 30(1): 93-109.

Behdad A (1994) Belated Travelers: Orientalism in the Age of Colonial Dissolution. Durham and London: Duke University Press.

Boer N (2016) Settlers and laborers: The afterlife of indenture in early South African Indian writing. Research in African Literatures 47(4): 21-35.

Brink JN (1904a) Ceylon en de Bannelingen. Amsterdam: H.A.U.M.

Brink JN (1904b) Recollections of a Boer POW in Ceylon. Amsterdam: H.A.U.M.

Brohier RL (2015) Prisoners of the Boer War in Ceylon and the Dutch East Indies (Revised and reprinted by Brohier D and Woodruff, RA). Colombo: Neptune Publications.

Burger AP (1936) Worsteljare: Herinneringe van Ds. A.P. Burger, Veldprediker by die Republikeinse Magte tydens die Tweede Vryheidsoorlog (Ed. Burger AJV). Cape Town, Pretoria, and Bloemfontein: Nationale Pers, Beperk.

Burton R (2011 [1876]) Two Trips to Gorilla Land and the Cataracts of the Congo (Cambridge Library Collection - African Studies). Cambridge: Cambridge University Press. doi:10.1017/ CBO9781139035088

Ceylon Observer (1900) Weekly edition, 14 September. Readex World Newspaper Archive.

Coetzee JM (1988) White Writing: On the Culture of Letters in South Africa. New Haven, CT and London: Yale University Press. 
Datta PK (2011) The interlocking worlds of the Anglo-Boer War in South Africa and India. In: Hofmeyr I and Williams M (eds) South Africa and India: Shaping the Global South. Johannesburg, ZA: Wits University Press, 56-81.

De Prikkeldraad: Orgaan van de Krijgsgevangenen te Diyatalawa (1900), 10 September. Newspaper/ Koerant 33. Bloemfontein, ZA: War Museum of the Boer Republics.

Die Burger (1934) Hoe 'n Krygsgevangene Boer ontsnap het. 21 May: 3. Stellenbosch University Library (microfilm).

Desai A and Vahed G (2016) The South African Gandhi: Stretcher-Bearer of Empire. Stanford, CA: Stanford University Press.

De Villiers JL (1904) Hoe Ik Ontsnapte: Verhaal van een Merkwaardige Ontsnapping van een Boer uit Engelsch-Indie. Amsterdam: Hoveker \& Wormser.

Fabian J (2002/1983) Time and the Other: How Anthropology Makes its Object. New York: Columbia University Press.

FAK Elektroniese Sangbundel (2014) Federasie van Afrikaanse Kultuurvereniging. Available at: http://www.fak.org.za/wp-content/uploads/blerkas/woorde/143.txt (accessed April 2017).

Ferreira OJO (1997) Boeregeïnterneerdes in Portugal tydens die Anglo-Boereoorlog (1899-1902) en hulle tydverdrywe [Boer internees in Portugal during the Anglo-Boer War (1899-1902) and their leisure activities]. Historia 42(2): 33-56.

Goswami M (2002) Rethinking the modular nation form: Toward a sociohistorical conception of nationalism. Comparative Studies in Society and History 44(4): 770-799.

Handbook for Travellers in India and Ceylon, including the Provinces of Bengal, Bombay, and Madras, (the Panjab, North-West Provinces, Rajputana, Central Provinces, Mysore, etc.) the Native States and Assam (1892). London: John Murray. HathiTrust Digital Library.

Hofmeyr I (2012) South Africa's Indian Ocean: Boer prisoners of war in India. Social Dynamics 38(3): 363-380.

Hofmeyr I (2013) Gandhi's Printing Press: Experiments in Slow Reading. Cambridge, MA: Harvard University Press.

Howell J (2013) Nursing empire: Travel letters from Africa and the Caribbean. Studies in Travel Writing 17(1): 62-77.

Jewell JR (2003) Using barbaric methods in South Africa: The British concentration camp policy during the Anglo-Boer War. Scientia Militaria 3(1). DOI: http://dx.doi.org/10.5787/31$1-140$.

Keck S (2015) Involuntary sightseeing: Soldiers as travel writers and the construction of colonial Burma. Victorian Literature and Culture 43(2): 389-407.

Mackenzie JM (2005) Empires of travel: British guide books and cultural imperialism in the nineteenth and twentieth centuries. In: Walton JK (ed.) Histories of Tourism: Representation, Identity and Conflict. EBSCO Publishing: E-book.

Mills S (1991) Discourses of Difference: An Analysis of Women's Travel Writing and Colonialism. London: Routledge.

Nasson B (2010) The War for South Africa: The Anglo-Boer War 1899-1902. Cape Town: NB Publishers.

Pratt ML (1992) Imperial Eyes: Travel Writing and Transculturation. London and New York: Routledge.

Reddy ES (1999) India and the Anglo-Boer War. Available at: http://www.mkgandhi.org/articles/ boer_war.htm (accessed April 2017).

Smethurst P (2008) Introduction. In: Kuehn J and Smethurst P (eds) Travel Writing, Form, and Empire: The Poetics and Politics of Mobility. New York: Routledge. 
Smith IR and Stucki A (2011) The colonial development of concentration camps (1868-1902). Journal of Imperial and Commonwealth History 39(3): 417-437.

Soske J (2017) Internal Frontiers: African Nationalism and the Indian Diaspora in TwentiethCentury South Africa. Athens, OH: Ohio University Press.

Van der Hoeven T (1901) Gevangen op Ceylon. Utrecht, NL: Bosch.

Van der Watt JS (1905) Leven der Boeren-krijgsgevangenen op Ceylon. Pretoria: ZA Boekhandel.

Van Wyk Smith M (2003) The Boers and the Anglo-Boer War (1899-1902) in the twentiethcentury moral imaginary. Victorian Literature and Culture 31(2): 429-446.

Von Braun CJAE (1903) Taktische Eindrucke wahrend des sudafrikanischen Krieges in Natal 1899-1900 erganzt wahrend der Kriegsgefangenschaft in St Helena 1901-1902. Berlin, DE: Eisenschmidt.

War Office (1905) General Questions Relating to Boer \& Foreign Prisoners of War Taken During the South African War, 1899-1902. London: Harrison and Sons. 